\title{
Recurrent glomerulonephritis after renal transplantation
}

DOI:

10.1097/MNH.0000000000000643

\section{Document Version}

Final published version

Link to publication record in Manchester Research Explorer

\section{Citation for published version (APA):}

Chukwu, C., Middleton, R., \& Kalra, P. (2020). Recurrent glomerulonephritis after renal transplantation. Current Opinion in Nephrology \& Hypertension, 29(6). https://doi.org/10.1097/MNH.0000000000000643

\section{Published in:}

Current Opinion in Nephrology \& Hypertension

\section{Citing this paper}

Please note that where the full-text provided on Manchester Research Explorer is the Author Accepted Manuscript or Proof version this may differ from the final Published version. If citing, it is advised that you check and use the publisher's definitive version.

\section{General rights}

Copyright and moral rights for the publications made accessible in the Research Explorer are retained by the authors and/or other copyright owners and it is a condition of accessing publications that users recognise and abide by the legal requirements associated with these rights.

\section{Takedown policy}

If you believe that this document breaches copyright please refer to the University of Manchester's Takedown Procedures [http://man.ac.uk/04Y6Bo] or contact uml.scholarlycommunications@manchester.ac.uk providing relevant details, so we can investigate your claim.

\section{OPEN ACCESS}




\title{
Recurrent glomerulonephritis after renal transplantation
}

\author{
Chukwuma A. Chukwu ${ }^{\mathrm{a}, \mathrm{b}}$, Rachael Middleton ${ }^{\mathrm{a}}$, and Philip A. Kalra ${ }^{\mathrm{a}, \mathrm{b}}$
}

\begin{abstract}
Purpose of review
The current understanding of the incidence, predisposing factors, pathophysiology and effective treatment of recurrent glomerulonephritis (RGN) in renal transplants remains at best patchy and at worst, completely lacking. Current reports have been limited by inconsistencies in study design, sample populations and lengths of follow-up. Making sense of the available evidence will provide the tools to support transplant nephrologists in their management of allograft donors and recipients.
\end{abstract}

\section{Recent findings}

With better survival of renal allografts, RGN has become a dominant factor influencing allograft survival. Evidently, the risk of recurrence is proportional to the incremental time posttransplantation. The proposed risk factors for RGN include but are not limited to the severity of primary glomerulonephritis (PGN), younger recipient age, live-related donor allograft, minimal HLA mismatch, steroid avoidance and nonuse of induction therapy. Unfortunately, these findings are derived from retrospective cohort and registry studies; hence, true causality for RGN is hard to prove.

\section{Summary}

The management of RGN is improving, as we gain greater understanding of its pathophysiology, including the genetic, alloimmune and autoimmune contributions to recurrence. With better pretransplant risk stratification, posttransplant surveillance, novel biomarkers and new treatment strategies, we hope the transplant community will eventually have the tools to predict risk, prevent recurrence and personalise treatment of RGN.

Keywords

allograft failure, biomarkers, recurrent glomerulonephritis, renal transplantation

\section{INTRODUCTION}

Glomerulonephritis remains one of the leading causes of end-stage renal disease (ESRD) worldwide $\left[1,2^{\prime \prime}\right]$ It represents the cause of ESRD in 23, 32, 42 and $48 \%$ of the renal transplant population of the UK, USA, Australia and China, respectively [3-6]. Kidney transplantation is associated with both superior quality of life and a survival advantage over dialysis [2"]. Unfortunately, the lifespan of renal allografts is finite, and so are the associated lifesaving benefits. The management of renal allografts is therefore aimed at achieving optimum graft function for the longest possible time by preventing and/ or mitigating the factors that cause graft loss [7].

In recent decades, improvements in the pre, peri and postoperative management of transplants, immunosuppressive therapy and cardiovascular disease prevention have led to better short to mediumterm survival of renal allografts [8]. Unfortunately, these improvements have not translated into appreciable improvements in long-term allograft survival [9-11]. Whereas the frequency of acute rejection has undoubtedly reduced, recurrence of primary renal disease, once thought to be a minor player in allograft outcomes, is now the third most common cause of allograft loss after immunologic rejection and death with functioning transplant $\left[2^{*}, 12\right]$. More cases of RGN are being diagnosed as renal allografts survive beyond the first few years of transplantation. Transplant physicians need to acknowledge and understand the potential impact of RGN on allograft outcomes in order to provide

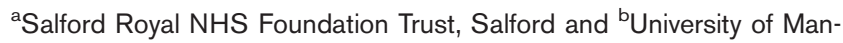
chester, Manchester, UK

Correspondence to Chukwuma A. Chukwu, Department of Renal Medicine, Salford Royal NHS Foundation Trust, Stott Lane, Salford M6 8HD, UK. Tel: +447711854640; e-mail: chukwuma.chukwu@nhs.net

Curr Opin Nephrol Hypertens 2020, 29:636-644

DOI:10.1097/MNH.0000000000000643 


\section{KEY POINTS}

- With the increasing prevalence of recurrent primary renal disease, the need to understand the risks and impact of RGN on allograft outcomes has become necessary.

- Primary glomerulonephritis such as MPGN, FSGS, membranous nephropathy and $\lg \mathrm{AN}$ are more likely than secondary glomerulonephritis, to recur in allografts with FSGS and MPGN associated with earlier recurrence and poorer graft outcomes.

- 'There are wide variations in the reported incidence and predictors of RGN, which are likely due to differences in biopsy practices, length of follow up, histologic diagnostic approach and widely differing sample populations.

- Several potential biomarkers that can predict the onset and progression of RGN have been identified, but they still require further population-wide validation to assess their accuracy and reliability.

- To date, there is no consensus on the best and effective treatments for the different forms of recurrent PGN, although the anti-CD20 antibody, rituximab, has shown great promise in cases of FSGS, membranous nephropathy and MPGN.

adequate risk assessments and counselling of potential kidney transplant recipients (KTRs) and their donors [13"']. Certainly, information regarding the epidemiology, pathophysiology and prognosis of RGN has increased and has led to improved risk stratification, better surveillance, earlier diagnosis and better treatment [12]. Nevertheless, significant knowledge gaps still exist in predicting which patients are at-risk, identifying disease biomarkers, judging of severity and prognostication. Understanding these factors is essential for better planning and prioritization of interventional strategies before irreversible damage has occurred in the allografts [14].

This review summarizes current evidence on the epidemiology, biomarkers, treatment and outcomes of RGN in transplant recipients with the commonest PGN: Immunoglobin A nephropathy (IgAN), focal segmental glomerulosclerosis (FSGS), membranoproliferative glomerulonephritis (MPGN) and membranous nephropathy. It highlights areas that may benefit from further research.

\section{REVIEW METHODOLOGY}

A literature search was carried out in February 2020 that included the published literature since June 2018 on the recurrence of glomerulonephritis in renal allografts. Information was retrieved from
Medline through the NICE healthcare data base advanced search (NICE HDAS) using the keywords 'Renal transplant', 'Allograft', 'Recurrent glomerulonephritis', 'IgA nephropathy', 'Membranous nephropathy', 'Focal segmental glomerulosclerosis', 'Membranoproliferative glomerulonephritis' in the title/abstract. A total of 275 articles were identified of which 58 were considered relevant to the topic. Other manuscripts were located through the reference list of relevant articles. These articles were evaluated based on the following criteria: how current the article was, if the article addressed research questions on the prevalence, predictors, outcomes, treatment or biomarkers of one or more of the recurrent PGNs in adults. Some articles were included that were published before 2018, as they had established important concepts and knowledge, which is currently relevant.

\section{EPIDEMIOLOGY OF RECURRENT GLOMERULONEPHRITIS}

The reported incidence of RGN has varied from 3 to $20 \%\left[13^{\prime \prime}, 15-24\right]$, the variations thought to be the result of differences in biopsy practices, lack of histological diagnoses in late presentations of ESRD and variable lengths of follow up. Also, variations in clinical presentations have resulted in failure to diagnose clinically asymptomatic cases $\left[13^{-*}, 25,26\right]$. Furthermore, biopsy specimens are not always subjected to precise and complete histological analysis. Hence, some RGNs have been misrepresented as other causes of late allograft dysfunction $\left[13^{-\prime}, 27\right]$. A recent study reported a recurrence rate of $11 \%$ and a median time to recurrence of 15 months amongst 862 KTR whose primary disease was biopsy-proven glomerulonephritis [28]. Another study reported an incidence of $19.7 \%$ amongst $183 \mathrm{KTR}$ followed for a mean period of 8.5 years and resulted in the loss of up to $55.6 \%$ of the affected allografts [23]. A large registry study by Jiang et al. [2"] included 7236 KTR of which 4025 had biopsy-proven PGN, followed up for a median period of 6.1 years; glomerulonephritis was identified in 7\% (511) of allografts (both primary and secondary native glomerulonephritis) and 10.5\% (424 out of 4025) of patients with PGN. Table 1 summarizes the incidences, time to recurrence and outcomes of the individual primary glomerulonephritis.

\section{RISK FACTORS FOR RECURRENT GLOMERULONEPHRITIS}

The ability to predict which KTR will develop RGN would be invaluable in pretransplant counselling, enabling the physician to personalise preventive and surveillance strategies and to initiate timely 
Table 1. Summary of recent studies showing prevalence and outcomes of each of the four primary glomerulonephritis

\begin{tabular}{|c|c|c|c|c|c|c|}
\hline GN type & $\begin{array}{l}\text { Study details (Ref. and } \\
\text { study period) }\end{array}$ & $\begin{array}{l}\text { Study } \\
\text { population }\end{array}$ & $\begin{array}{l}\text { Mean/ } \\
\text { median } \\
\text { Follow-up } \\
\text { period }\end{array}$ & $\begin{array}{l}\text { Incidence } \\
\text { of RGN }\end{array}$ & $\begin{array}{l}\text { Time to } \\
\text { recurrence }\end{array}$ & Outcome \\
\hline \multirow[t]{6}{*}{$\begin{array}{l}\text { Focal segmental } \\
\text { glomerulosclerosis }\end{array}$} & $\begin{array}{l}\text { Uffing et al. [37"-"] } \\
\text { International multicentre study } \\
\quad(2005-2015)\end{array}$ & 176 (primary idiopathic FSGS) & 5.0 years & $32 \%(57 / 176)$ & 1.5 months & $\begin{array}{l}\text { GL RGN vs. non- } \\
\quad R G N=39 \text { vs. } 15 \% \\
H R=4.8\end{array}$ \\
\hline & $\begin{array}{l}\text { Singh et al. [28] } \\
\text { WisARD (1994-2013) }\end{array}$ & 298 & 6.3 years & $13 \%(39 / 298)$ & 3.7 months & - \\
\hline & $\begin{array}{l}\text { Jiang et al. [2"] ANZDATA } \\
\quad(1985-2013)\end{array}$ & 975 & 6.1 years & $10.4 \%(101 / 975)$ & 6.7 months & $\begin{array}{l}5 \text { years DCGS }=55.6 \\
\text { vs. } 86.6 \% \\
\text { HR- } 1.83\end{array}$ \\
\hline & $\begin{array}{l}\text { Park et al. [23] } \\
\text { Korea (1982-2017) }\end{array}$ & 47 (first KT) & 8.5 years & $25.5 \%(12 / 47)$ & - & - \\
\hline & Francis et al. [39] & 736. (first KT) & 5.0 years & $10.3 \%(76 / 736)$ & - & $\begin{array}{l}5 \text { years } G S=52 \text { vs. } \\
83 \%\end{array}$ \\
\hline & $\begin{array}{l}\text { Allen et al. [22] } \\
\text { ANZDATA (1985-2014) }\end{array}$ & 1043 & 7.7 years & $10 \%(144 / 1403)$ & - & 5 years $\mathrm{GS}=57 \%$ \\
\hline Total & & 3275 & & $429 / 3275,13 \%$ & & \\
\hline \multirow[t]{5}{*}{ IgA nephropathy } & $\begin{array}{l}\text { Singh et al. [28] } \\
\text { WisARD (1994-2013) }\end{array}$ & 306 & 6.3 years & $8.8 \%(27 / 306)$ & 33.7 months & - \\
\hline & $\begin{array}{l}\text { Garnier et al. [81] } \\
\text { France (2003-2014) }\end{array}$ & 67 & 6.0 years & $20.8 \%(14 / 67)$ & - & GL 21.4 vs. $10.4 \%$ \\
\hline & $\begin{array}{l}\text { Jiang et al. [2"] } \\
\text { ANZDATA (1985-2013) }\end{array}$ & 2393 & 6.1 years & $9.7 \%(231 / 2392)$ & 4.63 years & $\begin{array}{l}5 \text { years } D C G S=88.3 \\
\quad \text { vs. } 90.2 \% \\
H R=4.49\end{array}$ \\
\hline & $\begin{array}{l}\text { Park et al. [23] } \\
\text { Korea (1982-2017) }\end{array}$ & 95 & 8.5 years & $20 \%(19 / 95)$ & - & - \\
\hline & $\begin{array}{l}\text { Allen et al. [22] } \\
\text { ANZDATA (1985-2014) }\end{array}$ & 2501 & 7.7 years & $9 \%(225 / 2501)$ & - & 5-year GS-58\% \\
\hline Total & & 5362 & & $516 / 5362,9.6 \%$ & & \\
\hline \multirow{4}{*}{$\begin{array}{l}\text { Membranoproliferative } \\
\text { glomerulonephritis/ } \\
\text { mesangial-capillary } \\
\text { glomerulonephritis }\end{array}$} & $\begin{array}{l}\text { Jiang et al. [2"] } \\
\text { ANZDATA (1985-2013) }\end{array}$ & 348 & 6.1 years & $15.5 \%(54 / 348)$ & 1.87 years & $\begin{array}{l}5 \text {-year DCGS- }=44.6 \\
\text { vs. } 79.5 \% \\
\text { HR-3.14 }\end{array}$ \\
\hline & $\begin{array}{l}\text { Wilson et al. [57] } \\
\text { ANZDATA (1996-2016) }\end{array}$ & 190 & 2.74 years & $18 \%(34 / 190)$ & - & $\begin{array}{l}\text { GL from disease } \\
\text { recurrence- } M P G N \\
\text { vs. all other } \\
\text { GNs }=32 \text { vs. } 5 \%\end{array}$ \\
\hline & $\begin{array}{l}\text { Park et al. [23] } \\
\text { Korea (1982-2017) }\end{array}$ & 14 & 8.5 years & $21.4 \%(3 / 14)$ & - & - \\
\hline & $\begin{array}{l}\text { Allen et al. [22] } \\
\text { ANZDATA (1985-2014) }\end{array}$ & 376 & 7.7 years & $16 \%(61 / 376)$ & & 5 -year GS $=30 \%$ \\
\hline Total & & 928 & & $152 / 928,16.4 \%$ & & \\
\hline \multirow[t]{5}{*}{$\begin{array}{l}\text { membranous } \\
\text { nephropathy }\end{array}$} & $\begin{array}{l}\text { Singh et al. [28] } \\
\text { WisARD (1994-2013) }\end{array}$ & 81 & 6.3 years & $16 \%(13 / 81)$ & 11.7 months & - \\
\hline & $\begin{array}{l}\text { Yang et al. [82] } \\
\text { ANZDATA (1998-2010) }\end{array}$ & 167 & 5.6 years & $11.4 \%(19 / 16)$ & 3.6 years & $\begin{array}{l}47 \% \text { graft loss. Hazard } \\
\text { ratio for GL- } M N \text { vs. } \\
\text { non-MN }=1.55\end{array}$ \\
\hline & $\begin{array}{l}\text { Jiang et al. [2"] } \\
\text { ANZDATA (1985-2013) }\end{array}$ & 309 & 6.1 years & $12.3 \%(38 / 309)$ & 3.93 years & $\begin{array}{l}\text { 5-year DCGS- RGN vs. } \\
\text { non-RGN }=70 \text { vs. } \\
88.3 \% \\
H R=2.20\end{array}$ \\
\hline & $\begin{array}{l}\text { Park et al. [23] } \\
\text { Korea (1982-2017) }\end{array}$ & 9 & 8.5 years & $22.2 \%(2 / 9)$ & - & - \\
\hline & $\begin{array}{l}\text { Allen et al. [22] } \\
\text { ANZDATA (1985-2015) }\end{array}$ & 357 & 7.7 years & $13.7 \%(49 / 357)$ & - & 5 -year GS $=59 \%$ \\
\hline Total & & 923 & & $121 / 923,13.1 \%$ & & \\
\hline
\end{tabular}

ANZDATA, Australia and New Zealand Dialysis and Transplant Registry; CR, complete remission; DCGS, death-censored graft survival; FSGS, focal segmental glomerulosclerosis; FU, follow-up; GL, graft loss; GN, glomerulonephritis; GS, graft survival; HR, hazard ratio; IgAN, IgA nephropathy; MCGN,

mesangiocapillary glomerulonephritis; $M N$, membranous nephropathy; MPGN, membranoproliferative glomerulonephritis; PR, partial remission; PY, patient-years; RGN, recurrent glomerulonephritis; WisARD, Wisconsin allograft recipient database. 
treatment. Unfortunately, inconsistencies in the reported predictors of RGN has made generalizability and establishing causal relationships challenging $\left[13^{-"}, 29\right]$. Several risk factors for RGN have been reported (Table 2). Some of the reported predictors include younger age at transplantation
$[2 * 19,22,23,30]$, male sex $[2 ", 19]$, shorter duration of primary renal disease history [23], low/zero HLA mismatch [22], steroid avoidance/early steroid withdrawal [22,31], shorter total ischemic time [22], live-related donor transplantation $[16,19,32,33]$, nonuse of lymphocyte-depleting

Table 2. Summary of prevalence, risks, biomarkers, available and potential future treatments of recurrent glomerulonephritis

\begin{tabular}{|c|c|c|c|c|}
\hline & FSGS & $\operatorname{IgAN}$ & MPGN & MN \\
\hline Recurrence rates ${ }^{a} \%$ & $10-35$ & $8.8-20$ & $15-21$ & $11-22$ \\
\hline $\begin{array}{l}\text { Median time to } \\
\text { recurrence }\end{array}$ & $1.5-12$ months & $2-5$ years & 4 months -24 years & $1-4$ years \\
\hline $\begin{array}{l}\text { Graft loss at } 5 \text { years } \\
\text { with recurrence \% }\end{array}$ & $20-40$ & $2-16$ & $30-70$ & $30-40$ \\
\hline Risk predictors & $\begin{array}{l}\text { Younger age } \\
\text { (inconsistent) } \\
\text { Aggressive course of } \\
\text { original disease } \\
\text { Previous failed } \\
\text { transplant } \\
\text { LRT }\end{array}$ & $\begin{array}{l}\text { Zero HLA mismatch } \\
\text { Younger age } \\
\text { Crescents in native } \\
\text { disease } \\
\text { LRT } \\
\text { Absence of Steroid use } \\
\text { at baseline } \\
\text { (inconsistent) }\end{array}$ & $\begin{array}{l}\text { LRT } \\
\text { Low Complement level } \\
\text { Presence of monoclonal } \\
\quad \text { proteins } \\
\text { Preemptive } \\
\text { transplantation }\end{array}$ & $\begin{array}{l}\text { Severity of } \\
\text { pretransplant } \\
\text { proteinuria. } \\
\text { Pretransplant Anti- } \\
\text { PLA2R antibody level } \\
\text { LRT }\end{array}$ \\
\hline Screening & Proteinuria & $\begin{array}{l}\text { Proteinuria } \\
\text { Serum Creatinine }\end{array}$ & $\begin{array}{l}\text { Complement levels } \\
\text { Proteinuria, } \\
\text { Serum Creatinine }\end{array}$ & $\begin{array}{l}\text { Pretransplant Anti- } \\
\text { PLA2R } \\
\text { Proteinuria } \\
\text { Serum creatinine }\end{array}$ \\
\hline Potential Biomarkers & $\begin{array}{l}\text { Apolipoprotein A-lb } \\
\text { Serum/urine SuPAR } \\
\text { Cardiolipin like } \\
\text { cytokine factor } 1 \\
\text { CLCF } 1 \\
\text { Anti-CD40 antibody } \\
\text { Anti-ATIR antibody }\end{array}$ & $\begin{array}{l}\text { GD-lgA1 } \\
\lg A 1-\lg G \text { specific } \\
\text { autoantibody } \\
\text { CD89 Complexes }\end{array}$ & $\begin{array}{l}\text { Complement factors } \\
\text { C3, C9, C3 nephritic } \\
\text { factor, Complement } \\
\text { regulatory proteins eg } \\
\text { Clusterin \& } \\
\text { Vitronectin. } \\
\text { Apolipoprotein E }\end{array}$ & $\begin{array}{l}\text { Anti-PLA2R } \\
\text { Anti-THSD7A } \\
\text { CD19, CD20, CD138, } \\
\text { CD34 } \\
\text { Auto antibodies to } \\
\text { podocyte antigens } \\
\text { AR, SOD2, } \alpha \text { ENO } \\
\left.\text { [1 }{ }^{-\cdots}\right]\end{array}$ \\
\hline $\begin{array}{l}\text { Best available } \\
\text { treatment }\end{array}$ & $\begin{array}{l}\text { Plasmapheresis with } \\
\text { rituximab }\end{array}$ & $\begin{array}{l}\text { Corticosteroids } \\
\text { improved proteinuria } \\
\text { but higher risk of } \\
\text { infections } \\
\text { MPA- mixed results } \\
\text { Alkylating agents for } \\
\text { crescentic lgAN }\end{array}$ & $\begin{array}{l}\text { Rituximab for lg- } \\
\text { mediated MPGN } \\
\text { Eculizumab (mixed } \\
\text { results) for } \\
\text { Complement } \\
\text { mediated MPGN. } \\
\text { Other complement } \\
\text { inhibitors undergoing } \\
\text { trials } \\
\text { Antivirals for HCV Treat } \\
\text { monoclonal } \\
\text { gammopathy }\end{array}$ & $\begin{array}{l}\text { Anti CD20 MAB- } \\
\text { Rituximab } \\
\text { Alkylating agents } \\
\text { (Cyclophosphamide) } \\
\text { in combination with } \\
\text { corticosteroids }\end{array}$ \\
\hline $\begin{array}{l}\text { Possible future } \\
\text { therapies }\end{array}$ & $\begin{array}{l}\text { Anti-CD40 antibody } \\
\text { Lucatumumab [50'] }\end{array}$ & $\begin{array}{l}\text { Tyrosine kinase } \\
\text { inhibitor Fostamatinib } \\
\text { [49], MBL pathway } \\
\text { inhibitor OMS721, } \\
\text { B-cell activating factor } \\
\text { inhibitor Atacicept } \\
\text { [50"] } \\
\text { Insulin like growth } \\
\text { factor } 1 \text { inhibitor } \\
\text { octreotide [80] }\end{array}$ & $\begin{array}{l}\text { Proteasome inhibitor } \\
\text { (Bortezomib) for } \\
\text { monoclonal } \\
\text { gamopathy } \\
\text { associated MPGN } \\
\text { [66] }\end{array}$ & $\begin{array}{l}\text { Proteasome inhibitor } \\
\text { (Bortezomib [83]) } \\
\text { Anti-CD38 MABs } \\
\text { (Daratumumab and } \\
\text { Isatuximab) [84] } \\
\text { New anti-CD20 MABs } \\
\text { (Ofatumumab and } \\
\text { Obinutuzumab [84] }\end{array}$ \\
\hline
\end{tabular}

$A R$, aldose reductase; $A T I R$, angiotensin receptor II type 1; $\alpha E N O$, alpha enolase; GD-lgAl, galactose-deficient immunoglobulin $A 1 ; H C V$, hepatitis $C$ virus; HLA, human leucocyte antigen; LRT, live related donor; MAB, monoclonal antibody; MBL, mannose-binding lecithin complement pathway.

aData from studies within the last 5 years. 
induction agents [33] and shorter duration of pretransplant dialysis $[22,33]$. There is an evident lack of consensus on the majority of the proposed risk factors. Jiang et al. [2"] identified live donor transplantation and male sex as risk factors for RGN, while Allen et al. [22] and An et al. [24] found no link between RGN and one or both of these factors. The increased risk of recurrence in live related donor kidneys may suggest a genetic contribution to some RGN. Also, certain HLA haplotypes have been linked to RGN [34,35]. Early steroid withdrawal as a predictor of RGN has been reported by some studies [22] but not corroborated by others [36]. Amongst glomerulonephritis subtypes, the majority of studies have reported MPGN and FSGS as the most commonly recurring forms of RGN $\left[2^{*}, 20,22,32,33\right]$. However, studies of Southeast Asian populations reported IgAN as the commonest RGN [21,24].

\section{IMPACT OF RECURRENT GLOMERULONEPHRITIS ON GRAFT OUTCOMES}

There is clear evidence of significant detrimental effects of RGN on allograft survival, but variations exist amongst studies. Graft losses of $8-50 \%$ have been reported at 5 years posttransplantation $[19,21,23]$. In one study, KTRs with RGN were three times as likely to lose their grafts as those without RGN [2"]. Favi et al. [27] evaluated the long-term graft survival of 426 KTR of which 99 (23\%) had PGN, comparing the effects on graft survival of RGN, acute rejection and chronic allograft nephropathy (CAN). Respectively, KTRs with RGN had a 10-year graft loss of $42 \%$ compared with $30 \%$ for acute rejection and $23 \%$ for CAN [27]. Jiang et al. [2"] reported a higher allograft loss with recurrent MPGN and FSGS than with recurrent IgAN. Similar outcomes were observed by Singh et al. [28] and Canas et al. [32] but not by $\mathrm{Yu}$ et al. [21] who noted a poorer outcome amongst Taiwanese KTRs with recurrent IgAN [21], suggesting that both epidemiology and outcomes of glomerulonephritis may be influenced by ethnic differences.

\section{PATHOPHYSIOLOGY, BIOMARKERS AND TREATMENT OF SUBTYPES OF RECURRENT PRIMARY GLOMERULONEPHRITIS}

Table 2 summarizes the prevalence rates, potential diagnostic biomarkers, current and potential future treatment strategies of RGNs.

\section{FOCAL AND SEGMENTAL GLOMERULOSCLEROSIS}

The reported incidence of recurrent FSGS varies widely amongst studies ranging from as low as 9\% in some studies to as high as 55\% in orders. Smaller studies tend to report higher incidence (17-55\%), while registry studies have reported lower incidence $(9-15 \%)$ [37"']. More recent studies report incidents of between 10 and $35 \%\left[2^{*}, 22,23,37^{-*}, 38,39\right]$. The wide variations are likely due to differences in patient selection and grouping within the different studies. Firstly, FSGS is not a specific disease entity but rather a histologic pattern of injury. Resulting from a range of glomerular insults, which could be idiopathic (but immune-mediated), infective, genetic, toxic or a secondary maladaptive response to nephron loss $[40,41]$. Secondly, some of these underlying aetiologies reoccur at varying rates in kidney allografts. Although idiopathic FSGS has a high recurrence rate, due to the suspected but still elusive circulating permeability factor [42], genetic and secondary FSGS have a much lower risk of recurrence $[43,44]$. Therefore, aggregating all cases of FSGS, with widely varying underlying kidney insults, into one cohort could conceivably confound the analysis of FSGS recurrence. Furthermore, the FSGS lesions in the native and transplant kidneys of a patient may sometimes have different causes (e.g. a genetic cause in the native kidney and a maladaptive cause in the allograft). Consequently, without identifying and grouping patients on the basis of their underlying cause (such as with genetic testing), statements regarding reoccurrence rates should be viewed with some degree of scepticism. Recurrent FSGS is associated with a five-fold increase in graft loss when compared to KTRs with primary FSGS but nonrecurrence [37"']. Most recurrences occur early with a median time of 1.5-12 months in primary FSGS $\left[37^{-\cdot}, 45\right]$. The early and high recurrence rates of primary FSGS has been attributed to the presence of a circulating permeability factor in the sera of KTRs, the identity of which has been the subject of ongoing research $[42,46]$. Savin et al. [47] first demonstrated that rats exposed to sera of patients with recurrent FSGS developed albuminuria, while Gallon et al. [48] later described a case of rapidly recurrent FSGS in a living donor recipient in which there was a reversal of the histopathologic and clinical features of FSGS in the same allograft after it was explanted and retransplanted into a different recipient without native FSGS. The most studied candidate circulating factor is the soluble urokinase plasminogen activating receptor (SuPAR). High pretransplantation levels of SuPAR have been linked to increased risk of FSGS 
recurrence posttransplantation [13"']. SuPAR is believed to cause podocyte foot process effacement and proteinuria by activating podocyte $\beta 3$ integrin $[42,49]$. Other circulating factors under investigation include anti-CD40 auto-antibody, Apolipoprotein A-lb (ApoA-lb) and cardiotrophin-like cytokine factor-1 (CLCF1) [42]. Podocyte foot processes are believed to be the main sites of injury in most forms of primary FSGS [42]. Lucatumumab, an anti-CD40 antibody, is currently in development for the treatment of FSGS [13"']. Corticosteroids, calcineurin inhibitors (CNIs), plasmapheresis, immunoadsorption, rituximab, cyclophosphamide and Abatacept/ belatacept have all been used, in varying combinations and with varying degrees of success, for the treatment of FSGS [37"']. A recent study by Uffing et al. [43] found that plasmapheresis with rituximab was the only remission inducing treatment amongst 75 KTR with recurrent FSGS. Compared with idiopathic FSGS, most genetic forms FSGS are less likely to reoccur. Genetic FSGS have defective podocyte components, such as in podocin and nephrin; therefore, their risk of recurrence in allografts is low, as these allografts are less likely to have same podocyte defects $\left[50^{-}\right]$.

\section{IgA NEPHROPATHY}

The reported incidence of IgA nephropathy (IgAN) varies in the literature because of the reasons already mentioned. Centres that performed protocol biopsies have reported a higher rate of recurrence (3050\%) [51]. However, as expected, registry reports suggest lower incidence, 5.4 and $10.8 \%$ at 5 and 10 years, respectively [52]. Aberrantly glycosylated IgA1 has been identified as an important element in the pathogenesis of IgAN resulting in the production of galactose deficient IgA1 (Gd-IgA1) [53]. In one study involving 60 KTR with biopsy-proven IgAN followed up for a median period of 8.6 years, the pretransplant levels Gd-IgA1, serum IgA, IgG glycan specific autoantibodies and CD89 complexes were found to be significantly higher in the recurrence group than the nonrecurrence and healthy control groups, and predicted IgAN recurrence, disease progression and allograft failure [54,55]. Suzuki et al. [52] characterized and validated a mAb, KM55 that can detect serum as well as glomerular Gd-IgA1 deposits with high specificity using a novel lectinindependent Gd-IgA1 ELISA. This assay can also distinguish between Gd-IgA1 deposits in IgAN from non Gd-IgA1-IgA deposits that occur in lupus nephritis, membranous nephropathy, hepatitis C infection and liver failure [53,56"']. KM55, when fully developed, could revolutionize the diagnosis of IgAN and provide a tool for risk assessment and surveillance for recurrent IgAN [55,56"']. Immunosuppressive agents in recurrent IgAN have had little impact on eGFR decline, but they have been associated with significant adverse events. Steroids improve proteinuria, but at the expense of increased adverse events [54,56"']. MMF has had mixed results, while rituximab and tacrolimus provided no benefit $\left[5^{-"}\right]$. Current trials are investigating the value of the tyrosine kinase inhibitor Fostamatinib, OMS721 a mAb that inhibits the mannosebinding lecithin complement pathway, and a B-cell activating factor blocker, Atacicept in primary IgAN $[57,58]$.

\section{MEMBRANOPROLIFERATIVE GLOMERULONEPHRITIS}

MPGN is characterized by mesangial proliferation and expansion, endocapillary proliferation, diffuse basement membrane thickening and reduplication caused by immune complex deposition [20,22,33]. The old classification of MPGN (types I, II and III) was based on the location and appearance of immune deposits in the glomerulus, but this provided very little information about the underlying pathogenesis [57]. The latest classification is based on the mechanism of injury and broadly divides MPGN into immune complex-mediated (IC-MPGN) (presence of immune complexes and complement in biopsy) and complement-mediated MPGN (CMPGN) (presence of complement without immune complexes) [59]. Most studies on recurrent MPGN were based on the old system of classification and have reported recurrence rates ranging from 18 to $65 \%$ [60]. Compared with other RGN, MPGN is associated with a poorer 5-year allograft survival and a shorter time to graft loss [61]. Complement factors C3 to C9, and complement regulatory proteins vitronectin and clusterin, have been suggested as potential biomarkers of complement-mediated MPGN [58]. The persistence or recurrence of hypocomplementemia and or monoclonal proteins posttransplantation have also been shown to predict MPGN recurrence [57].

There are suggestions that C3 glomerulopathy may be responsible for most cases of MPGN recurrence [62]. However, this has been difficult to prove, as most studies were based on the old classification system [63-67]. In 2016, Alasfer et al. [68] undertook a singlecentre retrospective study of recurrent MPGN amongst KTRs transplanted over a 20-year period and assessed the incidence and outcomes of recurrent MPGN using the new classification system. Out of a total of 34 patients who received 40 allografts, $88 \%$ of the pretransplant MPGN was classified as IC-MPGN, while $12 \%$ was classified as C-MPGN. Recurrence 
occurred in 18 out of 40 allografts (45\%) of which 16 were IC-MPGN, and two were C-MPGN. Living related allografts, preemptive transplantations, low complement level and presence of monoclonal gammopathy were factors associated with a higher rate of IC-MPGN recurrence. Due to the very small number of recurrent C-MPGN in the cohort, predictors for C-MPGN were not assessed. Half of the patients with recurrence lost their allografts. Allograft survival was not statistically different, although there was a trend towards worse survival in the group with recurrence [66].

Treatment outcomes of recurrent MPGN have not been encouraging. In addition to antiproteinuric treatment, MMF with or without steroids has shown varying degrees of success in native kidney MPGN $[69,70]$ but not so much in transplant MPGN. Long-term use of alkylating agents has been limited by the increased risk of malignancy and infections [71]. Rituximab with or without plasmapheresis has shown inconsistent results $\left[13^{-"}, 69\right]$ as has eculizumab [72",73], Perhaps the new classification system will make it possible to tailor the right treatment to the right underlying disease, such as using plasmapheresis and rituximab for immune complex MPGN [74-76], whilst anticomplement therapy could be useful in complement-mediated disease. Complement inhibitors that are currently available for such treatment include eculizumab (anti-C5 complement antibody), Compostin (CP40, a soluble peptide C3 complement inhibitor), soluble CR1 (a recombinant cell surface glycoprotein that regulates C3 convertase) as well as monoclonal antibodies against C3, factor B and properdin [77-79]. Most of these therapies are still undergoing clinical trial evaluation, but some have shown great promise in C-MPGN.

\section{MEMBRANOUS NEPHROPATHY}

Primary membranous nephropathy is characterized by subepithelial deposits comprising immunoglobulin (usually IgG4), antigen and complement components. The recurrence rate posttransplantation is between 7 and 50\% [75]. In a study of 63 KTR with biopsy-proven membranous nephropathy followed up with protocol biopsy for a median period of 77 months, a $48 \%$ histologic recurrence rate was observed [73]. The discovery of autoantibodies against the podocyte PLA2R, and more recently the antithrombospondin type- 1 domain-containing 7A (THSD7A), has provided a better understanding of the pathophysiology and made the diagnosis of idiopathic membranous nephropathy much easier [74]. In cases of anti-PLA2R MN, recurrence is related to the same antibody that caused the original disease [76], and the level of circulating autoantibody at transplantation has been shown to correlate with the risk and severity of recurrence and the likelihood of remission following treatment of recurrence [75]. In one study of 26 KTR with membranous nephropathy, a positive anti-PLAR2 pretransplantation predicted recurrence with a positive predictive value of 83\% [74]. Gupta et al. [74] have now shown that an anti-PLA2R level more than $29 \mathrm{RU} / \mathrm{ml}$ (normal $<14 \mathrm{RU} / \mathrm{ml}$ ) pretransplantation is a strong predictor of RGN with $85 \%$ sensitivity and $92 \%$ specificity. In contrast, Seitz-Polski et al. [56"'] found no correlation between the pretransplantation anti-PLA2R level and the risk of recurrence but instead noted a relationship between the 6-month posttransplantation anti-PLA2R level and recurrent membranous nephropathy. Regular monitoring of patients using anti-PLA2R assays and proteinuria quantification as well as prompt kidney biopsy when clinically indicated will help identify asymptomatic/early recurrence $\left[72^{*}, 80\right]$. The evidence for appropriate treatment of recurrent membranous nephropathy is limited and mainly extrapolated from the treatment of native kidney membranous nephropathy [73]. As with Native kidney MN, treatment is dependent on the degree of proteinuria ( $>1 \mathrm{~g}$ /day), the trajectory of GFR, the severity of histological changes and the autoantibody level [50"]. There is no evidence that modifying the posttransplant immunosuppression alters the risk of recurrence $\left[50^{*}\right]$. Alkylating agents in combination with corticosteroids (modified Ponticelli regime) have been the mainstay of treatment until recently [13"']. However, the use of rituximab has gained popularity in recent years [81]. One small study of 17 KTR treated with rituximab found that $82 \%$ achieved complete or partial remission [81]. Randomized control trials to determine the most effective treatment of recurrent membranous nephropathy are lacking.

\section{CONCLUSION}

The effects of posttransplant immunosuppression, the immunogenic burden of both the donor and recipient, as well as the altered autoimmune and alloimmune milieu of allografts, significantly impacts the pathophysiology of posttransplant glomerulonephritis, their progression and their response to treatment. Despite the progress made in understanding the epidemiology and pathophysiology of these conditions, significant gaps still exist in our knowledge of the risks, outcomes and efficacy of current treatment strategies. It is therefore crucial that we gain a better understanding of these diseases to enable active risk stratification, better monitoring and prompt effective treatment. Achieving this will 
require international, collaborative, multicentre prospective research studies with an emphasis on identifying and validating predictive biomarkers as well as providing evidence-based effective treatments. Encouragingly, there are several under development.

\section{Acknowledgements}

None.

\section{Financial support and sponsorship}

None.

\section{Conflicts of interest}

There are no conflicts of interest.

\section{REFERENCES AND RECOMMENDED READING}

Papers of particular interest, published within the annual period of review, have been highlighted as:

- of special interest

m. of outstanding interest

1. Lim WH, Johnson DW, McDonald SP, et al. Impending challenges of the burden of end-stage kidney disease in Australia. Med J Austr 2019; 211:374-380.

2. Jiang $\mathrm{SH}$, Kennard $\mathrm{AL}$, Walters GD. Recurrent glomerulonephritis following

- renal transplantation and impact on graft survival - Europe PMC Article Europe PMC. BMC Nephrol 2018; 19:344-355.

This registry study evaluated a 28 -year registry data on glomerulonephritis recurrence in KTRs with primary glomerulonephritis to determine the incidence of recurrence, predictors and outcomes of recurrent glomerulonephritis in renal allografts.

3. Evans K, Pyart R, Steenkamp R, et al. UK Renal Registry 20th Annual Report: introduction. Nephron 2018; 139:1-12.

4. Cosio FG, el Ters M, Cornell LD, et al. Changing kidney allograft histology early posttransplant: prognostic implications of 1-year protocol biopsies. Am J Transplant 2016; 16:194-203.

5. Cosio FG, Cattran DC. Recent advances in our understanding of recurrent primary glomerulonephritis after kidney transplantation. Kidney Int 2017; 91:304-314.

6. Liu ZH. Nephrology in China. Nature Reviews Nephrology 2013;9:1-6. https://doi.org/10.1038/nrneph.2013.146.

7. Matas AJ. Recurrent disease after kidney transplantation: it is time to unite to address this problem! Am J Transplant 2006; 6:2527-2528.

8. Coemans M, Süsal C, Döhler B, et al. Analyses of the short- and long-term graft survival after kidney transplantation in Europe between 1986 and 2015. Kidney Int 2018; 94:964-973.

9. Legendre C, Canaud G, Martinez F. Factors influencing long-term outcome after kidney transplantation. Transpl Int 2014; 27:19-27.

10. Uffing A, Pérez-Sáez MJ, la Manna G, et al. A large, international study on posttransplant glomerular diseases: the TANGO project. BMC Nephrol 2018; 19:239-236.

11. Günay $\mathrm{E}$, Çelebi $\mathrm{T}$, en $\mathrm{S}$, et al. Investigation of the factors affecting allograft kidney functions: results of 10 years. Transplant Proc 2019; $51: 1082-1085$.

12. Salvadori M. Recurrence of primary glomerulonephritis after renal transplantation. California: Juniper Publishers; 2017.

13. Lim WH, Shingde M, Wong G. Recurrent and de novo glomerulonephritis a. after kidney transplantation. Front Immunol 2019; 10:1944.

This review article presented a good summary of the risks, pathophysiology, available treatment and prognosis of RGN in kidney transplants. It also highlighted potential biomarkers of disease recurrence and laid emphasis on current management practices and how they affect allograft outcomes.

14. Kofman T, Oniszczuk J, Lang P, et al. Current insights about recurrence of glomerular diseases after renal transplantation. Nephrol Therap 2018; 14:179-188.

15. Hamburger J, Crosnier J, Noel L. Recurrent glomerulonephritis after renal transplantation. Ann Rev Med 1978; 1:67-72.

16. O'meara $Y$, Green $A$, Carmody $M$, et al. Recurrent glomerulonephritis in renal transplants: fourteen years' experience. Nephrol Dial Transplant 1989; $4: 730-734$.
17. Vangelista A, Fransca GM, Martella D, Bonomini V. Glomerulonephritis in renal transplantation. Nephrol Dial Transplant 1990; (Suppl 1):42-46.

18. Neumayer $\mathrm{HH}$, Kienbaum $M$, Graf $\mathrm{S}$, et al. Prevalence and long-term outcome of glomerulonephritis in renal allografts. Am J Kidney Dis 1993; 22:320-325.

19. Chailimpamontree W, Dmitrienko S, Li G, et al. Probability, predictors, and prognosis of posttransplantation glomerulonephritis. J Am Soc Nephrol 2009; 20:843-851.

20. Toledo K, Pérez-Sáez MJ, Navarro MD, et al. Impact of recurrent glomerulonephritis on renal graft survival. Transplant Proc 2011; 43:2182-2186.

21. Yu TM, Wen MC, Wu MJ, et al. Impact of posttransplantation glomerulonephritis on long-term outcome of kidney transplants: single-center 20-year experience. World J Surg 2012; 36:2923-2930.

22. Allen PJ, Chadban SJ, Craig JC, et al. Recurrent glomerulonephritis after kidney transplantation: risk factors and allograft outcomes. Kidney Int 2017; 92:461-469.

23. Park H, Park WY, Kang SS, et al. Clinical outcomes of kidney transplantation in patients with biopsy-proven glomerulonephritis. Transplant Proc 2018; 50:1009-1012.

24. An JN, Lee JP, Oh YJK, et al. Incidence of posttransplant glomerulonephritis and its impact on graft outcome. Kidney Res Clin Pract 2012; 31:219-226.

25. De Fijter JW. Recurrence of glomerulonephritis: an underestimated and unmet medical need. Kidney Int 2017; 92:294-296.

26. Abbas F, El Kossi M, Jin JK, et al. Recurrence of primary glomerulonephritis: review of the current evidence. World J Transplant 2017; 7:301-316.

27. Favi E, Pedroso JAR, Salerno MP, et al. Inferior long-term outcomes for kidney transplant recipients with an immunologically mediated primary renal disease. Exp Clin Transplant 2018; 16:541-545.

28. Singh $T$, Astor $B C$, Zhong $W$, et al. The association of acute rejection vs recurrent glomerular disease with graft outcomes after kidney transplantation. Clin Transplant 2019; 33:e13738. doi:10.1111/ctr.13738.

29. Pippias M, Stel VS, Aresté-Fosalba N, et al. Long-term kidney transplant outcomes in primary glomerulonephritis: analysis from the ERA-EDTA registry. Transplantation 2016; 100:1955-1962.

30. Moroni G, Casati C, Quaglini S, et al. Membranoproliferative glomerulonephritis type I in renal transplantation patients: a single-center study of a cohort of 68 renal transplants followed up for 11 years. Transplantation 2011; 91:1233-1239.

31. Floege J, Regele $H$, Gesualdo L. The ERA-EDTA database on recurrent glomerulonephritis following renal transplantation. Nephrol Dial Transplant 2014; 29:15-21.

32. Cañas L, López D, Pérez JF, et al. Recurrent glomerulonephritis in renal transplantation: experience in our renal transplantation center. Transplant Proc 2015; 47:2354-2356.

33. Moroni G, Longhi S, Quaglini S, et al. The impact of recurrence of primary glomerulonephritis on renal allograft outcome. Clin Transplant 2014; 28:368-376.

34. Green $H$, Rahamimov R, Rozen-Zvi B, et al. Recurrent membranoproliferative glomerulonephritis type I after kidney transplantation: a 17-Year single-center experience. Transplantation 2015; 99:1172-1177.

35. Avasare RS, Rosenstiel PE, Zaky ZS, et al. Predicting post-transplant recurrence of IgA nephropathy: the importance of crescents. Am J Nephrol 2017; 45:99-106.

36. Barbour S, Djurdjev O, Gill JS, et al. A propensity score matched analysis shows no adverse effect of early steroid withdrawal in nondiabetic kidney transplant recipients with and without glomerulonephritis. Kidney Int 2019; 96:460-469.

37. Uffing A, Pérez-Sáez MJ, Mazzali M, et al. Recurrence of FSGS after kidney m. transplantation in adults. Clin J Am Soc Nephrol 2020; 15:247-256.

This is the first international multicentre observational cohort study that described the incidence, predictors and treatment response of KTR with primary FSGS. This study was unique in that it was able overcome the logistical barrier of international multicentre collaborations and therefore was able to obtain a larger sample size. This will hopefully create an avenue for more international collaboration and pave the way for multicentre, prospective, international, randomized controlled trials on recurrent glomerulonephritis.

38. Olenski S, Scuderi $C$, Choo A, et al. Urinary tract infections in renal transplant recipients at a quaternary care centre in Australia. BMC Nephrol 2019; 20:1-7.

39. Francis A, Trnka P, McTaggart SJ. Long-term outcome of kidney transplantation in recipients with focal segmental glomerulosclerosis. Clin J Am Soc Nephrol 2016; 11:2041-2046.

40. Pollak MR. Focal Segmental Glomerulosclerosis. Genetic Dis Kidney 2008; 17:113-127.

41. Fogo $A B$. Causes and pathogenesis of focal segmental glomerulosclerosis. Nat Rev Nephrol 2015; 11:76-87.

42. Peev V, Hahm E, Reiser J. Unwinding focal segmental glomerulosclerosis. F1000Research 2017; 6:466.

43. Kang $H G, H a I S$, Cheong $H I$. Recurrence and treatment after renal transplantation in children with FSGS. BioMed Res Int 2016; 2016:6832971.

44. Maas RJH, Deegens JKJ, van den Brand JAJG, et al. A retrospective study of focal segmental glomerulosclerosis: clinical criteria can identify patients at high risk for recurrent disease after first renal transplantation. BMC Nephrol $2013 ; 14: 47$. 
45. Puig-Gay N, Jacobs-Cacha C, Sellarès J, et al. Apolipoprotein A-lb as a biomarker of focal segmental glomerulosclerosis recurrence after kidney transplantation: diagnostic performance and assessment of its prognostic value - a multicentre cohort study. Transplant Int 2019; 32:313-322.

46. Jacobs-Cachá C, Puig-Gay N, Helm D, et al. A misprocessed form of apolipoprotein A-I is specifically associated with recurrent focal segmental glomerulosclerosis. Sci Rep 2020; 10:1159-1167.

47. Savin VJ, Sharma R, Sharma M, et al. Circulating factor associated with increased glomerular permeability to albumin in recurrent focal segmental glomerulosclerosis. N Engl J Med 1996; 334:878-883.

48. Gallon L, Leventhal J, Skaro A, et al. Resolution of recurrent focal segmental glomerulosclerosis after retransplantation. N Engl J Med 2012; 366:1648-1649.

49. Wada T, Nangaku M. A circulating permeability factor in focal segmental glomerulosclerosis: the hunt continues. Clin Kidney J 2015; 8:708-715.

50. Yeo SC, Cheung CK, Barratt J. New insights into the pathogenesis of $\lg A$ nephropathy. Pediatr Nephrol 2018; 33:763-777.

This review article discussed the latest evidence on the pathogenesis of $\lg A$ nephropathy. It described the interplay between genetic, immunologic and environmental factors in the pathogenesis of $\lg A$ nephropathy and potential areas of therapeutic interventions.

51. Berthelot $L$, Robert $T$, Vuiblet $V$, et al. Recurrent IgA nephropathy is predicted by altered glycosylated IgA, autoantibodies and soluble CD89 complexes. Kidney Int 2015; 88:815-822.

52. Suzuki $H$, Yasutake J, Makita $Y$, et al. $\lg A$ nephropathy and $\lg A$ vasculitis with nephritis have a shared feature involving galactose-deficient $\lg \mathrm{A} 1$-oriented pathogenesis. Kidney Int 2018; 93:700-705.

53. Floege J. IgA nephropathy: toward more specific diagnosis (and rescue of snails). Kidney Int 2018; 93:542-544.

54. Lafayette RA, Canetta PA, Rovin BH, et al. A randomized, controlled trial of rituximab in IgA nephropathy with proteinuria and renal dysfunction. J Am Soc Nephrol 2017: 28:1306-1313.

55. Yu M, Kim Y-C, Koo HS, Chin HJ. Short-term antiproteinuric effect of tacrolimus is not related to preservation of the glomerular filtration rate in IgA nephropathy: a 5-year follow-up study. PLoS One 2017; 12:e0188375.

56. Floege J, Barbour SJ, Cattran DC, et al. Management and treatment of

- glomerular diseases (part 1): conclusions from a Kidney Disease: Improving Global Outcomes (KDIGO) Controversies Conference. Kidney Int 2019; 95:268-280.

The treatment of recurrent glomerulonephritis is commonly based on treatment protocols extracted from guidelines on management of native kidney glomerulonephritis. This recent publication provides a succinct summary of the latest management guidelines for primary glomerulonephritis and highlights ongoing developments in discovering new therapies for glomerulonephritis.

57. Wilson GJ, Cho Y, Teixiera-Pinto A, et al. Long-term outcomes of patients with end-stage kidney disease due to membranoproliferative glomerulonephritis: an ANZDATA registry study. BMC Nephrol 2019; 20:417-516.

58. Hohenstein $B, A$ mann $K$, Menne J. Membranoproliferative Glomerulonephritis und C3-Glomerulopathie. Der Internist 2019; 60:458-467.

59. Sethi S, Fervenza FC, Zhang Y, et al. C3 glomerulonephritis: clinicopathological findings, complement abnormalities, glomerular proteomic profile, treatment, and follow-up. Kidney Int 2012; 82:465-473.

60. Lorenz EC, Sethi $S$, Leung $N$, et al. Recurrent membranoproliferative glomerulonephritis after kidney transplantation. Kidney Int 2010; 77: $721-728$.

61. Zand L, Lorenz EC, Cosio FG, et al. Clinical findings, pathology, and outcomes of C3GN after kidney transplantation. J Am Soc Nephrol 2014; 25:1110-1117.

62. Lien $\mathrm{Y}-\mathrm{H}$, Scott $\mathrm{K}$. Long-term cyclophosphamide treatment for recurrent type I membranoproliferative glomerulonephritis after transplantation. Am J Kidney Dis 2000; 35:539-543.

63. Marques IDB, Ramalho J, David DR, et al. Rituximab in a B cell-driven regimen for the treatment of recurrent membranoproliferative glomerulonephritis after kidney transplantation. Int Urol Nephrol 2014; 46:2053-2054.

64. Farooqui $\mathrm{M}$, Alsaad $\mathrm{K}$, Aloudah $\mathrm{N}$, Alhamdan $\mathrm{H}$. Treatment-resistant recurrent membranoproliferative glomerulonephritis in renal allograft responding to rituximab: case report. Transplant Proc 2015; 47:823-826.
65. Damodar A, Mustafa R, Bhatnagar J, et al. Use of anti-CD20 antibody in the treatment of posttransplant glomerulonephritis. Clin Transplant 2011; 25:375-379.

66. Alasfar S, Carter-Monroe N, Rosenberg AZ, et al. Membranoproliferative glomerulonephritis recurrence after kidney transplantation: using the new classification. BMC Nephrol 2016; 17:7.

67. Feistle D-VK, Yango AF, Fischbach B, et al. Treatment of recurrent, postkidney transplant membranoproliferative glomerulonephritis with plasmapheresis and rituximab: a case report and literature review. Clin Nephrol 2019; 91:52-58.

68. Alasfar S, Carter-Monroe N, Rosenberg AZ, et al. Membranoproliferative glomerulonephritis recurrence after kidney transplantation: using the new classification. BMC Nephrol 2016; 17:1-9.

69. Ozkaya $\mathrm{O}, \mathrm{Nal}$ cacioglu $\mathrm{H}$, Tekcan $\mathrm{D}$, et al. Eculizumab therapy in a patient with dense-deposit disease associated with partial lipodystropy. Pediatr Nephrol 2014: 29:1283-1287.

70. Kaartinen K, Martola L, Räisänen-Sokolowski A, Meri S. Recurrent allograft C3 glomerulonephritis and unsuccessful eculizumab treatment. Clin Immunol 2018; 187:104-106.

71. Von Visger J, Cassol C, Nori U, et al. Complete biopsy-proven resolution of deposits in recurrent proliferative glomerulonephritis with monoclonal IgG deposits (PGNMIGD) following rituximab treatment in renal allograft. BMC Nephrol 2019; 20:53.

72. Leon J, Pérez-Sáez MJ, Batal I, et al. Membranous nephropathy posttrans-

- plantation: an update of the pathophysiology and management. Transplantation 2020; 103:1990-2002.

This study provided a concise review of the pathophysiology of membranous nephropathy with a summary guidance on how to investigate and manage patients with recurrent membranous nephropathy.

73. Grupper A, Cornell LD, Fervenza FC, et al. Recurrent membranous nephropathy after kidney transplantation: treatment and long-term implications. Transplantation 2016; 100:2710-2716.

74. Seitz-Polski B, Payré C, Ambrosetti D, et al. Prediction of membranous nephropathy recurrence after transplantation by monitoring of anti-PLA2R1 (M-type phospholipase A2 receptor) autoantibodies: a case series of 15 patients. Nephrol Dial Transplant 2014; 29:2334-2342.

75. Kattah A, Ayalon R, Beck LH, et al. Antiphospholipase A2 receptor antibodies in recurrent membranous nephropathy. Am J Transplant 2015; 15: 1349-1359.

76. Gupta G, Fattah $\mathrm{H}$, Ayalon R, et al. Pretransplant phospholipase A2 receptor autoantibody concentration is associated with clinically significant recurrence of membranous nephropathy postkidney transplantation. Clin Transplant 2016; 30:461-469.

77. Nester CM, Smith RJH. Complement inhibition in C3 glomerulopathy. Semin Immunol 2016; 28:241-249.

78. Schena FP, Esposito $P$, Rossini M. A narrative review on $\mathrm{C} 3$ glomerulopathy: a rare renal disease. Int J Mol Sci 2020; 21:1-18.

79. Zhang $Y$, Nester CM, Holanda DG, et al. Soluble CR1 therapy improves complement regulation in C3 glomerulopathy. J Am Soc Nephrol 2013; $24: 1820-1829$

80. Beck LH, Fervenza FC, Beck DM, et al. Rituximab-induced depletion of antiPLA2R autoantibodies predicts response in membranous nephropathy. J Am Soc Nephrol 2011; 22:1543-1550.

81. Sharma $A$, Hariharan S. Octreotide delaying the progression of recurrent $\lg A$ nephropathy after kidney transplantation. Kidney Transplant 2019; 6:e518.

82. Garnier AS, Duveau A, Demiselle J, et al. Early posttransplant serum IgA level is associated with $\lg A$ nephropathy recurrence after kidney transplantation. PLoS One 2018; 13:e0196101.

83. Yang $\mathrm{WI}$, Bose $\mathrm{B}$, Zhang $\mathrm{L}$, et al. Long-term outcomes of patients with endstage kidney disease due to membranous nephropathy: a cohort study using the Australia and New Zealand Dialysis and Transplant Registry. PLoS One 2019; 14:e0221531.

84. Passerini $P$, Malvica S, Tripodi F, et al. Membranous nephropathy (MN) recurrence after renal transplantation. Front Immunol 2019; 10:1326.

85. Barbari A. Pre and posttransplant refractory idiopathic membranous glomerulonephritis: the forgotten potential culprit. Exp Clin Transplant 2017; 15:483-489. 